\title{
The Relationship between Language Learning Strategies, Language Learning Beliefs, Motivation, and Proficiency: A Study of EFL Learners in Iran
}

\author{
Maedeh Ghavamnia \\ The University of Isfahan, Isfahan, Iran \\ Email: ghavamniam@yahoo.com \\ Zohreh Kassaian \\ The University of Isfahan, Isfahan, Iran \\ Azizollah Dabaghi \\ The University of Isfahan, Isfahan, Iran
}

\begin{abstract}
Since the emergence of strategy research in the 1970s many issues have been examined. One of these areas which has been favored in recent years is related to answering questions like 'what variables are related to the choice and the use of learner strategies?' and 'How strong is the influence of a certain variable?' As thus, the purpose of this study was to examine the relationship between strategy use on the one hand and three other variables (motivation, proficiency, and learners' beliefs) on the other hand. The participants of this study were homogenized in terms of age, gender, and major and were required to fill out three questionnaires and complete a TOEFL test. The first was the Strategy-Inventory for Language Learning (SILL) developed by R. Oxford (1990) to identify the general strategies ESL/EFL learners use. The second was the Beliefs about Language Learning Inventory (BALLI) developed by Horwitz (1988). This study also adopts Schmidt and Watanabe's (2001) model of language learning motivation. Finally, the CoefficientCorrelation was estimated to identify the relationship between the aforementioned variables in relation to strategy use. The results indicate that Persian students do use a number of language learning strategies, but that they show distinct preferences for particular types of strategies. The findings also reveal a positive relationship between strategy use and motivation, proficiency, and language learning beliefs. These results may be used in the future to inform pedagogy.
\end{abstract}

Index Terms-language learning strategies, language learning beliefs, proficiency, language learning motivation

\section{INTRODUCTION}

This study was conducted at the University of Isfahan in Iran. English is a foreign language taught to Iranian students from guidance school onto university. In spite of the amount of exposure to English its use in daily life is limited and the proficiency of the students does not meet expectations of the instructors. Although English is a prerequisite for higher education, most Iranian students cannot speak English fluently. Therefore, the purpose of this study is to explore variables that may contribute to an improvement in Iranian learners English. This study aims to identify the language learning strategies used by Iranian students and the relationship between the former variable in regards to language learning beliefs, motivation, and proficiency. This study is a response to a need for more language strategy research with students from different cultural backgrounds.

\section{LITERATURE REVIEW}

\section{A. Language Learning Strategies}

Second language strategy research dates back to the year 1975 (Grenfell \& Macaro, 2007). According to Cohen \& Macaro (2007), 'if there is one article which can be seen to have announced the birth of language learner strategy research, it was what the good language learner can teach us by Joan Rubin in 1975'. Since then, various theorists have contributed to the definition of language learning strategies (Grenfell \& Macaro, 2007). Various classification systems have sought to group individual strategies within larger categories. From them, the most frequently cited and applicable definitions of learning strategies to date is that of Rebecca Oxford (1990) who described learning strategies as 'specific actions taken by the learner to make learning easier, faster, more enjoyable, more self-directed, more effective, and 
more transferable to new situations' (p.8). Oxford (1990) in her Strategy Inventory for Language Learning (SILL) prescribes six categories namely: Memory strategies, cognitive strategies, compensation strategies, metacognitive strategies, affective strategies, and social strategies. Oxford's classification has been selected for this study because it is comprehensive, detailed, and systematic (Vidal, 2002).

\section{B. Beliefs about Language Learning}

Since the mid 1980s, learner beliefs have become a topic of research interest and have received an increasing amount of attention (Barcelos, 2003). Learner beliefs refer to "beliefs about the nature of language and language learning" (Barcelos, 2003, p. 8). They also seem to "have direct relevance to the understanding of student expectations of, commitment to, success in, and satisfaction with their language classes" (Horwitz, 1988). Learner beliefs connect naturalistically to learners' use of language learning strategies. Students' description of language learning strategy use, for instance, was found to be consistent with their stated beliefs about language learning (Wenden, 1987). Horwitz's system of beliefs about language learning, as reflected in the Beliefs about Language Learning Inventory (BALLI), which is the most widely used questionnaire for investigating learner beliefs (Barcelos, 2003) consists of the following five major areas: (a) beliefs about the difficulty of language learning, which concerns the general difficulty of learning a second language as well as perceptions of the difficulty of a specific target language; (b) foreign language aptitude, which concerns the existence of aptitude and opinions about the kind of individuals who possess it; (c) beliefs about the language learning process, which concerns student ideas about "what it means to learn a language and how to go about it" (Horwitz, 1999, p. 565); (d) beliefs about how to communicate; and (e) motivation and learner expectations (Horwitz, 1988, 1999). The present study adopts this system and adapts specific items in the BALLI.

\section{Language Learning Motivation}

Motivation comes from the Latin verb movere, which means to move (Pintrich, 2003). Motivation theories attempt to answer questions about "what gets individuals moving" and toward what activities or tasks (Pintrich \& Schunk, 2002). In second language research, "motivation provides the primary impetus to initiate learning in the L2 and later the driving force to sustain the long and often tedious learning process" (Dörnyei, 2005, p. 65). This present study adopts Schmidt and Watanabe's (2001) model of language learning motivation.

\section{Language Proficiency}

Language proficiency has been defined by various researchers. Some ways of determining proficiency include: selfratings (Oxford \& Nyikos, 1989); language achievement tests (Phillips, 1991); entrance and placement examinations (Mullins, 1992); language course grades (Mullins, 1992); years of language study (Watanabe, 1990). In this study, the proficiency of the learners has been determined based on the results of a TOEFL test which was completed by the participants.

\section{RESEARCH QUESTIONS}

1. What type of language learning strategies do the Iranian participants use?

2. What is the relationship between language learning strategies on the one hand and their beliefs, motivation, and language proficiency on the other hand?

\section{METHOD}

\section{A. Participants}

The participants for this study were selected from the Department of English at the University of Isfahan. They were all female under-graduate students majoring in Applied Linguistics and were in their early twenties. A total number of 80 students, selected based on a random sampling method, participated in this study.

\section{B. Instruments}

A version of the SILL (50-item version 7.0 for ESL/EFL) was used to collect data on the type and frequency of strategies used by the participants. The items on the questionnaire were required to be answered based on a Likert scale response using a five-interval scale of 'never of almost never true of me', 'usually not true of me', 'somewhat true of me', 'usually true of me', and 'always or almost always true of me'. The BALLI was used to identify the participants' beliefs in regards to language learning. In order to identify the students' level of motivation Schmidt and Watanabe's (2001) model of language learning motivation was adopted in this study. The proficiency level of the participants were determined based on an IBT TOEFL test extracted from 'How to prepare for the TOEFL IBT' book written by Pamela J. Sharp. The TOEFL is a standardized test for ESL/EFL students. It has proven to be a reliable and valid test used throughout the world to assess students' English proficiency. The instruments were piloted before data collection in order to identify and resolve any ambiguity if there was any. According to the results of the pilot test there was no need to translate any of the instruments used in this study.

\section{Data Collection}


The data for this study were collected from senior students majoring in applied linguistics. Before gathering the data, permission was received from their instructors. Students were also notified that they would be participating in a study and would be required to complete a TOEFL test and fill out three questionnaires. Two class sessions were dedicated for gathering the data. In the first session the 80 participants were required to complete the TOEFL test. In the second session they were required to fill out the SILL, BALLI, and the language learning motivation questionnaire. The students were reassured that there was no right or wrong answer, and that their responses would not affect their final grades.

\section{Data Analysis}

After piloting the instruments used in this study, the reliability of each instrument was calculated. The SILL questionnaire had an alpha reliability coefficient of 0.91 , the BALLI an alpha reliability coefficient of 0.85 , and Schmidt and Watanabe's (2001) questionnaire had an alpha reliability coefficient of 0.82 . The mean and standard deviation of the SILL questionnaire was estimated in order to identify the frequency of language learning strategies employed by Iranian learners. Following that the Pearson Correlation was estimated in order to identify the relationship between language learning strategies on the one hand and language learning beliefs, motivation, and proficiency on the other hand.

\section{RESULTS}

From the result of the SILL questionnaire it can be understood that the EFL students reported on using all six strategies. The table below shows the mean of the overall strategy use of the participants.

TABLE 1:

DESCRIPTIVE STATISTICS FOR LANGUAGE LEARNING STRATEGY

\begin{tabular}{|l|lll|l|}
\hline Strategy & Mean & Degree & Rank & N \\
\hline Cognitive & 3.81 & Generally used & 1 & $\mathbf{8 0}$ \\
\hline Metacognitive & 3.39 & Sometimes used & 2 & $\mathbf{8 0}$ \\
\hline Compensation & 3.18 & Sometimes used & 3 & $\mathbf{8 0}$ \\
\hline Memory & 3.03 & Sometimes used & 4 & $\mathbf{8 0}$ \\
\hline Affective & 3.00 & Sometimes used & 5 & $\mathbf{8 0}$ \\
\hline Social & 2.88 & Sometimes used & 6 & $\mathbf{8 0}$ \\
\hline
\end{tabular}

According to the results the participants reported on using all the six categories of language learning strategies. The most frequently used strategy being the cognitive strategy (Mean=3.81) and the least frequently used strategy being the social strategy (Mean=2.88). According to Oxford's index for interpretation of the LLS, the result of the questionnaires revealed that the participants sometimes used social, affective, compensation, metacognitive, and memory strategies. Cognitive strategies were generally used based on the results of the SILL questionnaire.

The results of the Pearson Correlation between language learning strategies and the other three variables under study showed a positive relationship in all three cases. The tables below reveal the strength of the relationship.

TABLE 2:

CORRELATION BETWEEN LANGUAGE LEARNING STRATEGY AND LANGUAGE LEARNING BELIEFS

\begin{tabular}{|ll|l|l|}
\hline & strategy & reading \\
\hline strategy & Pearson Correlation & 1 & .581 \\
& Sig. (2-tailed) & .000 \\
& $\mathrm{~N}$ & 80 & 80 \\
\hline reading & Pearson Correlation & .581 & 1 \\
& Sig. (2-tailed) & .000 & \\
$\mathrm{~N}$ & 80 & 80 \\
\hline
\end{tabular}


TABLE 3:

CORRELATION BETWEEN LANGUAGE LEARNING STRATEGY AND MOTIVATION

\begin{tabular}{|ll|l|l|}
\hline \multicolumn{2}{|c|}{} & motivation & strategy \\
\hline motivation & Pearson Correlation & 1 & .589 \\
& Sig. (2-tailed) & .001 \\
& $\mathrm{~N}$ & 80 & 80 \\
\hline strategy & Pearson Correlation & .589 & 1 \\
& Sig. (2-tailed) & .001 & \\
& $\mathrm{~N}$ & 80 & 80 \\
\hline
\end{tabular}

TABLE 4:

CORRELATION BETWEEN LANGUAGE LEARNING STRATEGY AND ENGLISH PROFICIENCY

\begin{tabular}{|ll|l|l|}
\hline \multicolumn{1}{|c|}{} & strategy & reading \\
\hline strategy & Pearson Correlation & 1 & .220 \\
& Sig. (2-tailed) & .003 \\
& $\mathrm{~N}$ & 80 & 80 \\
\hline reading & Pearson Correlation & .220 & 1 \\
& Sig. (2-tailed) & .003 & \\
& $\mathrm{~N}$ & 80 & 80 \\
\hline
\end{tabular}

\section{DISCUSSION}

This study showed that Iranian EFL learners were familiar with language learning strategies and this might imply them being active strategic users. The cognitive strategy was the most frequently used strategy in this study $(\mathrm{M}=3.81)$. After cognitive strategies, the second most frequently used strategy was metacognitive strategy $(M=3.39)$. Compensation strategy ranked third $(M=3.18)$. The fourth strategy from the top was the memory strategy $(M=3.03)$. The least language learning strategy reported on by the participants were the social and affective strategies.

The students in this study indicated a low level of preference for Socio-affective strategies. This is similar to the results of studies such as those by Chamot and Kupper (1989), Goh and Kwah (1997), and Magogwe and Oliver (2007). It may be that like students in Oxford's (1993) study, students in Iran are largely unaware of the potential of socioaffective strategies.

Of course, there are many studies which have resulted in different findings from the aforementioned studies (e.g. Magogwe \& Oliver, 2007; Oxford, 1990; Sheorey, 1999). One possible explanation for the different findings found in the studies mentioned above and many others might be related to the context of learning situation, which could have a strong influence on learners' choice of language learning strategies (Chamot, 2005; Cohen, 1998; Zhang, 2008). Some studies argue that the strategies frequently used by proficient language learners in an Asian FL (foreign language) context differ drastically from those in the North American SL (second language) context (Gu, 1996; LoCastro, 1994; Takeuchi et al., 1999; Takeuchi \& Wakamoto, 2001). The use of different types and numbers of strategies may also depend on the learner and setting in which learning occurs and the language task to be completed, suggesting a need for more studies on different learners in different settings. Some studies have indicated that Asian students showed reluctance to try new learning techniques and did not respond well to strategy training. Such differences led Politzer and McGroarty (1985) to conclude that many accepted "good" language-learning strategies may be based on ethnocentric assumptions, namely Western, about effective language learning. Further, when compared to learners in other cultural settings it is apparent that the combination of strategies preferred by the Iranian students is not the same as other learners.

The current study found a strong relationship between the participants' beliefs concerning language learning and their language learning strategies. Regarding motivation the findings of this study were in line with previous studies. There is now considerable support for the association between students' motivation and use of learning strategies (Elliot, McGregor, \& Gable, 1999; Lens, Simons, \& Dewitte, 2002; Pintrich, 1999; Pintrich \& De Groot, 1990; Schiefele, 1991). In terms of language learning strategy and language proficiency, in a large number of studies a positive relationship between the two aforementioned variables has been reported (Bruen, 2001; Glenn, 2000; Park, 1997; Sheorey, 1999). Oxford (2003) reports on multiple studies that have used her Strategy Inventory for Language Learning (SILL) to measure the relationship between strategy use and proficiency. Most have found the relationship to be of either a linear (e.g., Green \& Oxford, 1995; Oxford \& Ehrman, 1995) or curvilinear nature (e.g., Phillips, 1991). Overall, "In most but not all instances, the relationship is linear, showing that more advanced or more proficient students use strategies more frequently" (Oxford \& Burry-Stock, 1995, p.10).

\section{CONCLUSION}


The results of this study were consistent with the general findings of previous language learning strategy studies (Green \&Oxford, 1995; Magogwe \& Oliver, 2007; O'malley \& Chamot, 1990). Like previous research conducted outside the Iranian context, this study found more overall use of language learning strategies by more proficient and motivated students. At the same time the more positive their language learning beliefs, the more strategies they reported on using.

One of the limitations of this study was that data was only collected from one source with students majoring in the same field. As thus, generalization of the findings is limited. A more significant limitation was examining the participants as a whole and not making a distinction between the proficient and less proficient.

In terms of pedagogical implications, the results could imply the need for classroom pedagogy to explicitly integrate strategy instruction and to address the motivational aspect of learning for the purpose of motivating student involvement and enhancing learning effectiveness.

\section{REFERENCES}

[1] Barcelos, A. M. F. (2003). Researching beliefs about SLA: A critical review. In P. Kalja, \& A.M.F. Barcelos (Eds.). Beliefs about SLA: New research approaches. Norwell, MA: Kluwer Academic Press.

[2] Bruen, J. (2001). Strategies for success: Profiling the effective learner of German. Foreign Langue Annals, 34(3), 216-25.

[3] Chamot, A.U. (2005). Language learning strategy instruction: Current issues and research. Annual Review of Applied Linguistics. 25, 112-130.

[4] Chamot, A.U. \& Kupper, L. (1989). Learning strategies in foreign language instruction. Foreign Language Annals, $22(1), 13-$ 24.

[5] Cohen, A.D. (1998). Strategies in learning and using a second language. London: Longman.

[6] Cohen, A.D. \& Macaro, E. (2007). Language learner strategies: Thirty years of research and practice. Oxford: Oxford University Press.

[7] Dörnyei, Z. (2005). The psychology of the language learner. Mahwah, NJ: Lawrence Erlbaum Associates.

[8] Elliot, A. J., McGregor, H. A., \& Gable, S. (1999). Achievement goals, study strategies, and exam performance: A mediational analysis. Journal of Educational Psychology, 91(3), 549-563.

[9] Glenn, W. (2000). Language learning strategy use of bilingual foreign language learners in Singapore. Language Learning, 50, 203-244.

[10] Goh, C. \& Kwah, P.F. (1997). Chinese ESL students' learning strategies: A look at frequency, proficiency, and gender. Hong Kong Journal of Applied Linguistics, 2, 39-53.

[11] Green, J.M. \& Oxford, R.L. (1995). A closer look at learning strategies, L2 proficiency, and gender. TESOL Quarterly, 29(2), 261-97.

[12] Gu, P.Y. (1996). Robin Hood in SLA: What has the learner strategy research taught us? Asian Journal of English Language Teaching. 6, 1-29.

[13] Horwitz, E. K. (1988). The beliefs about language learning of beginning university foreign language students. Modern Language Journal, 72, 283-294.

[14] Horwitz, E. K. (1987). Surveying student beliefs about language learning. In A. Wenden \& J. Rubin (Eds.), Learner strategies in language learning (pp. 119-129). Englewood Cliffs, NJ: Prentice/Hall International.

[15] Lens, W., Simons, J., \& Dewitte, S. (2002). From duty to desire: the role of students' future time perspective and instrumentality perceptions for study motivation and self-regulation. In F. Pajares, \& T. Urdan (Eds.), Academic motivation of adolescents (pp. 221e245). Greenwich, CT: Information Age Publishing.

[16] LoCastro, V. (1994). Learning strategies and learning environments. TESOL Quarterly, 28, 409-414.

[17] Magogwe, J.M. \& Oliver, R. (2007). The relationship between language learning strategies, proficiency, age, and self-efficacy beliefs: A study of language learners in Botswana. System, 35, 338-352.

[18] Mullins, P. (1992). Successful English language strategies of students enrolled in the Faculty of Arts, Chulalongkorn University, Bangkok Thailand. United States International University.

[19] O'Malley, J. M. \& Chamot, A. U. (1990). Learning strategies in second language acquisition. Cambridge: Cambridge University Press.

[20] Oxford, R.L. (1990). Language learning strategies: What every teacher should know. Boston: Heinle \& Heinle.

[21] Oxford, R. (2003). Research on second language learning strategies. Annual Review of Applied Linguistics, 13, $175-187$.

[22] Oxford, R.L. \& Burry-Stock, J.A. (1995). Assessing the use of language learning strategies worldwide with the ESL/EFL version of the strategy inventory for language learning (SILL). System, 23(1), 1-23.

[23] Oxford, R. L., \& Ehrman, M. E. (1995). Adults' language learning strategies in an intensive foreign language program in the United States. System, 23(3), 359-356.

[24] Oxford, R.L. \& Nyikos, M. (1989). Variables affecting choice of language learning strategies by university students. Modern Language Journal, 73(3), 291-300.

[25] Park, G.P. (1997). Language learning strategies and English proficiency in Korean University students. Foreign Language Annals, 30(2), 211-221.

[26] Pintrich, P. R. (1999). The role of motivation in promoting and sustaining self-regulated learning. International Journal of Educational Research, 31, 459-70.

[27] Pintrich, P.R. (2003). A motivational science perspective on student motivation in teaching and learning contexts. Journal of Educational Psychology, 95(4), 667-686.

[28] Pintrich, P.R. \& DeGroot, E.V. (1990). Motivational and self-regulated learning components of classroom academic performance. Journal of Educational Psychology, 82(1), 33-40. 
[29] Pintrich, P.R., \& Schunk, D.H. (2002). Motivation in education: Theory, research, and application (2nd ed.). Upper Saddle River, NJ: Prentice Hall.

[30] Politzer, R., \& McGroarty, M., (1985). An exploratory study of learning behaviors and their relationship to gains in linguistic and communicative competence. TESOL Quarterly, 19, 103-124.

[31] Schiefele, U. (1991). Interest, learning, and motivation. Educational Psychologist, 26(3-4), 299-323.

[32] Sheorey, R. (1999). An examination of language learning strategy use in the setting of an indigenized variety of English. System, 27, 173-190.

[33] Takeuchi, O., Mine, H., Yoshida, H., \& Yoshida, S. (1999). Toward the establishment of country-by-country SILL norms. Language Laboratory. 36, 51-62.

[34] Takeuchi, O. \&Wakamoto, N. (2001). Language learning strategies used by Japanese college learners of English: A synthesis of four empirical studies. Language Education and Technology. 38, 21-43.

[35] Vidal, R.J. (2002). Is there a correlation between reported language learning strategy use, actual strategy use and achievement? Linuagem and Ensino, 5(1), 43-73.

[36] Watanabe, Y. (1990). External variables affecting learning strategies of Japanese EFL learners: Effects of entrance examination, years spent at college/university, and staying overseas. Unpublished master's thesis, Lancaster University, Lancaster, UK.

[37] Wenden, A. L. (1986). What do second-language learners know about their language learning? A second look at retrospective accounts. Applied Linguistics, 7, 186-201.

[38] Zhang, L.J. (2008). Constructivist pedagogy in strategic reading instruction: Exploring pathways to learner development in the English as a second language (ESL) classrooms. Instructional Science: An International Journal of the Learning Sciences, 36, 89-116.

Maedeh Ghavamnia is a post-graduate student at the University of Isfahan. She got her B.A. in Nutrition from the Medical University of Isfahan and afterwards decided to continue her education in TEFL. She got her M.A. at the University of Isfahan. Following that she was accepted in the $\mathrm{PhD}$ entrance examination at the University of Isfahan. Her fields of interest are first language acquisition, third language acquisition, psycholinguistics, and cognitive and meta-linguistic knowledge.

Zohreh Kassaian was born in Isfahan, Iran. She received her BA degree in English Language and Literature from The University of Isfahan, Isfahan, Iran in 1973 (as a top student); her MA in Teaching English as a Second Language from the University of Shiraz, Shiraz, Iran in 1987; and her PhD in Teaching English as a Second Language from Islamic Azad University, Tehran, Iran in1996. She is an assistant professor in the English Department of the Faculty of Foreign languages at the University of Isfahan. She is a permanent academic member and has held this position since 1978. She has participated in more than 20 national and international conferences and has more than 20 articles and several books published. Her subjects of interest are Psycholinguistics, Neurolinguistics, Applied Linguistics, Phonetics, and Translation.

Dr. Kassaian has been a member of several professional societies including International Systemic Functional Linguistics, Iran Society of Teaching English Language and Literature, and The International Society of Scientific Collaboration for Iran Recognition.

Azizollah Dabaghi completed his doctoral studies in language learning and teaching at the University of Auckland after being awarded with the University's prestigious Doctoral Scholarship. He has been involved in translation field for the last thirty years most which was spent in practical works as a Spontaneous Oral Translator in international relations. He also spent some years working as a Translator of official and legal deeds at the University of Isfahan, Iran. Currently, he is an Assistant Professor at the University of Isfahan, teaching and researching language acquisition and translation courses at both undergraduate and post-graduate levels. His main interests include translation and culture, legal translation, sociolinguistics, and second language acquisition. 